\title{
Androgen Receptor Positive
}

National Cancer Institute

\section{Source}

National Cancer Institute. Androgen Receptor Positive. NCI Thesaurus. Code C94297.

An indication that expression of AR has been detected in a sample. 